\title{
Modal Politik dan Modal Sosial Athari Gauthi Ardi Pada Kemenangan Pemilu Legislatif Tahun 2019 di Provinsi Sumatera Barat
}

\author{
Reninta Ananda ${ }^{1}$, Tengku Rika Valentina ${ }^{2}$ \\ ${ }^{12}$ Jurusan Ilmu Politik, Fakultas Ilmu Sosial dan Ilmu Politik, Universitas Andalas
}

\begin{abstract}
In the 2019 legislative elections in West Sumatra, social capital and political capital are one of the ways in which actors can compete with their political opponents, in order to attract the attention of the public to support it. Birner and Witmer state that the concept of political capital makes it possible to study local communities using social capital to achieve political goals, and Bourdieu also said that social capital is in the form of actual and potential resources owned by someone from an institutionalized and ongoing social network that provide collective support for its members. The focus of this study is to explain how Athari Gauthi Ardi used Political Capital and Social Capital as a tool to win himself in political contestation in the 2019 legislative elections. Parental power used by Athari Gauthi Ardi to win the 2019 legislative elections in West Sumatra. Researchers' assumptions emerge that one of Athari Gauthi Ardi's capitals is political capital owned by his parents. The purpose of this study is to determine the political capital and social capital utilized by Athari Gauthi Ardi in the 2019 legislative elections and the relationship between political capital and social capital to Athari Gauthi Ardi's victory in the 2019 legislative general election. This study used study case qualitative methods. The results of this study indicate that Athari Gauthi Ardi has sufficient capital, such as : (1) Parent's network and Ali Mukhni's network are used by Athari Gauthi Ardi. (2) Political support obtained by Athari Gauthi Ardi from the community, religious and traditional leaders, the PAN Party, and regional cadres from the West Sumatra of PAN party. (3) Athari Gauthi Ardi was intelligent woman with a tough personality, diligent and also can mingle with the community. (4) As well as sufficient economic capital owned by Athari Gauthi Ardi and his parents, who is a successful businessman.
\end{abstract}

Keywords: political capital and social capital, legislative elections, the winning of candidate

\section{Pendahuluan}

Penelitian mengenai modal sosial masih menarik untuk diteliti lebih lanjut, menurut Bourdieu dalam bukunya An Invitation to Reflexive Sociology mendefinisikanmodal sosial sebagai kumpulan sejumlahsumberdaya, baik aktual maupun potensialyang terhubung dengan kepemilikan jaringan atau relasi, yang sedikit banyak telahterlembaga dalam pemahaman dan pengakuan bersama (Baharuddin \& Purwaningsih, 2017). Menariknya, menurut John F. Halliweel dalambukunya yang berjudul Social Capital and Prosocial Behaviour Sources of Well-Being (2001:47) mengkaji klaim-klaim empiric tentang pentingnya modal sosial diantaranya; (1) modal sosial selalu penting untukpengembangan

*) Corresponding Author

Email : tengkurika@soc.unand.ac.id 
kapital manusia (Alfa Farah, Erlinda Puspita Sari, 2014). (2) modal sosial dianggap dapat meningkatkan kesejahteraan individu dan memberikebahagiaan yang subyektif. (3) modal sosial juga juga dianggap penting peranannyaguna meminimalisir ongkos dan resiko yangmungkin dikeluarkan dalam kegiatanekonomi. (4) modal sosial dapatmenggerakkan individu atau kelompok untukmelakukan mobilitas sosial secara vertikal. Modal sosial merupakan sumber daya sosial yang bisa digunakan sebagai investasi untuk bekerja bersama-sama demi mencapai tujuan bersama di dalam kelompok, dan juga dipandang sebagai investasi untuk mendapatkan sumber daya baru.Menariknya, modal sosial di sini tidak diartikan dengan materi, tetapi merupakan modal sosial yang terdapat pada seseorang, pada kelompok institusi keluarga, organisasi, dan semua hal yang dapat mengarah pada kerjasama (Solihah, 2019). Di Indonesia, calon legislatif dengan kepemilikan modal sosial dapat membantu pembentukan habitus (Bourdieu dalam Hussain (2013) Dalam (Ria et al., 2014) untuk siap bersaing di arena pertarungan politik yang baru sebagai strategi untuk mendapatkan dukungan suara masyarakat pada pemenangan Pemilu Legislatif. Hubungan antara habitus, ranah, dan modal sosial semua relevan dan saling bersinergi. Apabila ada salah satu dari ketiga hal ini hilang atau tidak dimiliki oleh aktor maka akan sulit bertarung dalam ranah politik. Maka dari itu, perlu adanya usaha yang keras, yang dilakukan oleh aktor dan tim strategi pemenangannya agar bisa memenangkan aktor dalam Pemilu Legislatif.
Selain itu, identitas yang melekat dalam habitus seorang aktor yang tercermin dari hasil konstruksi terkait pengalaman aktor memaknai realitas yang dihadapinya.Maka dari itu, aktor membutuhkan marketing politik, yang dilakukan oleh aktor untuk dapat menciptakan strategi berupa Image politik untuk dapat menarik minat masyarakat agar tertarik untuk memilih aktor tersebut pada pemilihan.Kemenangan yang diraih semata-mata bukan karena "mendompleng" dari eksistensi partainya atau organisasi sosial, melainkan juga kemampuan personal seorang aktor politik yang dapat mempengaruhi masyarakat untuk mendukungnya. Arena politik adalah tempat pertarungan aktor untuk mendapatkan legitimasi ataupun posisi strategis di pemerintahan yang di dalamnya terdapat modal sebagai penunjang tujuan.

Peneliti mencoba mengelompokan beberapa penelitian terdahulu yang berkaitan dengan modal politik, akan tetapi memiliki fokus kajian masing-masing seperti penelitian (Baharuddin \& Purwaningsih, 2017) dengan judul Modalitas Calon Bupati Dalam Pemilihan Umum Kepala Daerah Tahun 2015 (Studi Kasus: Indah Putri Andriani Sebagai Bupati Terpilih Di Kabupaten Luwu Utara Provinsi Sulawesi Selatan). Modal sosial merupakan salah satu modalitas yang dapat dipandang sebagai investasi untuk mendapatkan hubungan yang harmonis serta kepercayaan dari masyarakat. Oleh karena itu peneliti menganggap modal sosial sebagai salah satu komponen utama guna menggerakkan mobilitas massa, sehingga saling menguntungkan untuk mencapai kemajuan bersama. 
Selanjutnya (Solihah, 2019) Jurnal Wacana Politik dengan judul Modal Sosial Jeje-Adang Dalam Pemilihan Kepala Daerah Kabupaten Pangandaran Tahun 2015.Penelitian ini terfokus pada tiga modal yaitu, modal sosial, modal politik dan juga modal ekonomi untuk dapat menjelaskan kemenangan kandidat.

Dari beberapa penelitian yang sudah penulis jelaskan diatas ada sejumlah pembahasan yang cukup berbeda yang belum dibahas oleh penelitian sebelumnya yaitu, pada pembahasan (Baharuddin \& Purwaningsih, 2017) menjelaskan semua konsep modalitas, tidak hanya menjelaskan satu modalitas yang dimiliki oleh Indah Adi Indriani, tetapi peneliti lebih memfokuskan pada modal sosial yang kandidat miliki dalam kemenangnya di Pilkada serta juga menjelaskan modal sosial, ekonomi, dan budaya. Penelitian kedua, juga hanya memfokuskan pada modal sosial yang dimiliki pasangan kandidat pada kontestasi Pilkada, kedua penelitian ini juga lebih banyak menjelaskan kepercayaan politik masyarakat terhadap terpilihnya kandidat dalam Pilkada.

Perbedaan

penelitian

terdahulu dengan penelitian yang dibahas oleh penulis yaitu, (1) pada aspek modal politik yang dimanfaatkan oleh aktor, baik itu modal politik yang ia miliki ataupun modal politik yang dimiliki oleh kelompok tertentu. Dengan memanfaatkan kepopuleran atau modal politik orang lain, yang bertujuan untuk memenangkan kontestasi politik. Penulis berasumsi pada penelitian ini bahwasannya seorang aktor dapat memenangkan kontestasi politik dengan menggunakan modal politik individu atau modal politik orang lain yang masih memiliki hubungan kekeluargaan dengan sang kandidat, untuk dapat memobilisasi suara pemilih agar memilihnya dalam pemilihan legislatif. (2) perbedaan yang kedua yaitu, pada fokus penelitian ini menjelaskan mengenai aspek modal sosial dan modal politik oleh seorang aktor maupun kelompok dalam melakukan Marketing Politik, agar mampu menciptakan strategi politik yang baik, yang memiliki tujuan untuk memenangkan kontestasi politik.

Berbagai strategi politik dilakukan oleh masing-masing bakal calon anggota legislatif, untuk dapat memenangkan pemilihan umum legislatif. Seperti yang sudah dijelaskan, bahwasannya modal tidak hanya dimiliki dari seorang individu saja, melainkan modal politik juga dapat dimanfaatkan dari kelompok tertentu, yang sudah memiliki komitmen tertentu sebelumnya, hal tersebutlah yang banyak dilakukan oleh caleg-caleg untuk dapat memenangkan dirinya pada pemilihan umum legislatif. Banyak dari bakal caleg yang tidak memiliki latar belakang dari ranah politik yang dengan mudah mendapatkan kursi menuju Senayan.Fenomena ini terjadi pada pemilu legislatif tahun 2019.Lolosnya tiga orang caleg perempuan dari Sumatera Barat, yang memiliki hubungan dengan kepala daerah di Sumatera Barat.Menjelaskan bahwa modal tidak terletak pada diri individu caleg tersebut, tetapi pada jaringan politik yang beliau miliki.

Pada Tanggal 27 Mei 2019 Indonesia melaksanakan pemilu serentak, untuk pemilihan Presiden dan Wakil Presiden, DPR RI, DPD dan 
DPRD Provinsi dan kota. Sumatera Barat merupakan salah satu daerah yang ikut melaksanakan pemilihan serentak.Pada pemilihan legislatif tahun 2019, Sumatera Barat mampu meloloskan tiga calon anggota legislatif perempuan.Ini merupakan jumlah terbanyak caleg perempuan yang lolos, sejak pemilu digelar pasca-reformasi 1999.Seperti berita yang diterbitkan oleh berita online Kompas.

"Berdasarkan hasil rekapitulasi suara KPU, dari 14 calon anggota DPR RI terpilih asal daerah pemilihan Sumbar, tiga diantaranya adalah perempuan. Mereka adalah Nevi Zuairina dari PKS, Lisda Hendrajoni dari Nasdem, dan Athari Gauthi Ardi dari PAN (https://regional.kompas.com/read/ 2019/05/18/16544831/sejarahterjadi-tiga-caleg perempuan-asalsumbar-lolos-ke-senayan)

Ketiga Caleg perempuan yang mampu menduduki kursi empuk di Senayan, memiliki hubungan yang dekat dengan politisi yang berpengaruh di wilayah Sumatera Barat. Nevi Zuairina merupakan istri dari Gubernur Sumatera Barat dua periode, sedangkan Lisda Hendrajoni merupakan istri dari Bupati Pesisir Selatan dan Athari Gauthi Ardi merupakan anak dari Epyardi Asda. Dia merupakan anggota DPR RI yang menjabat selama tiga periode.

Dari ketiga Caleg perempuan tersebut, Athari Gauthi Ardi merupakan Caleg perempuan dengan perolehan suara tertinggi dibandingkan dengan Caleg perempuan Nevi Zuairina dan Lisda Hendrajoni. Athari Gauthi Ardi merupakan wajah baru dalam dunia politik, Athari belum pernah ikut berpartisipasi dalam pencalonan Caleg pada pemilu sebelumnya. Ini merupakan pencalonan pertama Athari pada Pileg tahun ini, dan langsung memenangkan pemilihan dengan suara terbanyak pada Dapil I Sumatera Barat dari Caleg Perempuan lainya.

Tabel 1.1

Persentase Jumlah Suara Caleg Perempuan Yang Menang pada Pemilihan Legislatif Tahun 2019

\begin{tabular}{ccccc}
\hline No & Nama & Partai & Jumlah Suara & Dapil \\
\hline $\mathbf{1}$ & Athari Ghauti Ardi & PAN & $\mathbf{8 2 . 9 8 2}$ & Dapil I \\
2 & Nevi Zuairina & PKS & 52.141 & Dapil II \\
3 & Lisda Hendrajoni & Nasdem & 37.326 & Dapil I \\
\hline
\end{tabular}

Sumber : Data Olahan Peneliti 2019

Penjelasan pada Tabel 1.1, bahwasannya caleg perempuan Athari Gauthi mampu mendapatkan suara tertinggi dibandingkan dengan dua caleg perempuan lainnya.Dari latar belakang kedua caleg perempuan tersebut, mereka merupakan orang-orang yang tidak asing bersinggungan dengan perpolitikan. Mereka merupakan istri dari kepala daerah di Sumatera Barat yaitu, Lisda Hendrajoni merupakan istri Bupati Pesisir Selatan Hendrajoni, dan Nevi Zuairina 
merupakan istri dari Gubernur Sumatera Barat Irwan Prayitno yang lolos pada Dapil II Sumatera Barat, oleh karena itu mereka dapat lebih mudah dikenal oleh masyarakat Sumatera Barat. Tidak hanya cukup modal sebagai istri dari kepala daerah, mereka dikalahkan oleh caleg pendatang baru dan masih muda yaitu, Athari Gauthi Ardi.

Pada pemilu legislatif Tahun 2019 kursi yang diperebutkan oleh para Caleg di Dapil I Sumatera Barat berbeda dari tahun sebelumnya yaitu hanya 7 kursi. Pada Pileg kali ini 6 partai politik berhasil meloloskan calon anggota legislatifnya, partai tersebut adalah PAN, Demokrat, PKS, Nasdem, Golkar, dan Gerindra. Caleg petahana yang kembali mencalonkan dirinya pada pemilu tahun 2019 namun kalah dalam pemilu yaitu Alex Indra Lukman dan Andre Syaiful.Wajah pendatang baru yang berhasil memenangkan kursi Dapil I yaitu, Athari Gauthi Ardi dan Lisdawati Hendrajoni. Athari Gauthi juga mengalahkan mantan Bupati Solok pada pemilihan, Athari mampu mendapatkan suara tertinggi di Kabupaten Solok.Bersaing dengan orang yang sudah pernah memimpin dan berpengaruh di Kabupaten Solok, Athari menunjukan bahwa beliau mampu mengambil hati masyarakat Kabupaten Solok.Athari berhasil meraup suara di 14 kecamatan di Kabupaten Solok, seperti yang diberitakan oleh berita online Kabar Sumbar.

Athari juga memanfaatkan sosial media untuk memperkenalkan dirinya kepada masyarakat, Athari menggunakan media sosial seperti Facebook, tidak hanya pada akun pribadi Athari saja, bahkan juga dengan menggunakan akun relawan untuk mempromosikan Athari. Seperti pada postingan akun relawan untuk Caleg Athari Gauthi Ardi juga sering menyebutkan bahwa Athari Gauthi merupakan putri dari Epyardi Asda. Tentu hal tersebut dilakukan oleh Athari Gauthi dengan tanpa alasan, kepopuleran orang tuanya terdahulu berusaha dimanfaatkan kembali oleh Athari Gauthi pada pemilihan legislatif tahun 2019 untuk mendapatkan simpati dari masyarakat

Sebagai anak dari Epyardi Asda, yang merupakan anggota DPR RI yang menjabat selama tiga periode. Athari Gauthi Ardi tentu sudah memiliki modal politik yang dapat di gunakan untuk menarik minat pemilih untuk memilihnya.Ditengahtengah persaingan politik yang semakin intens, kehadiran modal politik menjadi sangat penting. Dalam hal ini, pihak yang memiliki modal politik relatif besar dibandingkan dengan pesaingnya akan diuntungkan. Begitu juga sebaliknya, pihak yang memiliki modal politik jauh lebih kecil akan kesulitan untuk bisa bersaing apalagi memenangkan kompetisi politik.

Faktor lain yang juga membantunya mengenalkan diri kepada masyarakat, yakni hubungan keluarga. Athari merupakan putri sulung dari mantan anggota DPR RI selama dua periode, Epyardi Asda. Athari juga maju dari dapil yang sama dengan ayahnya, yakni Sumbar I. Menurut Athari, priviledge sebagai anak politisi senior dapat dimanfaatkan untuk mengenal masyarakat di dapilnya https://www.msn.com/idid/berita/nasional/cerita-caleg- 
terpilih-berjuang-melawan-politikuang/ar-AAGvkEX)

Menurut Asrinaldi, terkait banyaknya Caleg perempuan yang lolos pada pemilu 2019 memiliki hubungan dengan kekerabatan dengan kepala daerah di Sumatera Barat sangat memiliki keuntungan. Seperti yang diberitakan pada berita online Kompas.

"Pengamat politik Universitas Andalas Dr Asrinaldi mengatakan, lolosnya sejumlah istri kepala daerah di Sumbar merupakan fenomena politik yang menarik.Menurutnya, para istri kepala daerah itu bukanlah kader partai dari bawah, namun hanya ditarik menjadi calon legislatif."Mereka ditarik jadi caleg karena kepopuleran dari suaminya yang menjadi kepala daerah.Artinya, mereka menumpang kepopuleran suaminya,"(https://kilasdaerah.komp as.com/jawatengah/read/2019/05/1 3/12050771/3-istri-kepala-daerahdi-sumatera-barat-melenggang-kesenayan)

\section{Modal sosial merupakan} sumber daya sosial yang bisa digunakan sebagai investasi untuk bekerja bersama-sama demi mencapai tujuan bersama di dalam kelompok, dan juga dipandang sebagai investasi untuk mendapatkan sumber daya baru.Menariknya, modal sosial di sini tidak diartikan dengan materi, tetapi merupakan modal sosial yang terdapat pada seseorang, pada kelompok institusi keluarga, organisasi, dan semua hal yang dapat mengarah pada Kerjasama (Solihah, 2019) Seperti yang terjadi terhadap caleg Athari Gauthi Ardi, modal tidak terdap]at pada dirinya, tetapi modal terdapat pada pengaruh orang tuanya, yang sudah memiliki modal politik dan modal sosial yang dimanfaatkan oleh Athari Gauthi untuk mengingatkan kembali, bahwasannya Athari merupakan putri dari seorang Epyardi Asda, yang sudah pernah berbuat untuk Sumatera Barat.

Athari Gauthi Ardi dapat membuktikan bahwa Athari bisa lolos ke Senayan dengan perolehan jumlah suara 82.982 suara sah. Asumsi penulis pada penelitian ini bahwasannya salah satu modal politik yang dimiliki Athari Gauthi adalah karena pengaruh nama besar orang tuanya, yang merupakan mantan anggota legislatif dengan masa jabatan selama tiga periode. Tentu pada kemenangan Pileg 2019 Athari Gauthi Ardi memiliki modal politik yang ia gunakan dalam membantu pemenangannya pada Pileg tahun 2019.

Berdasarkan

beberapa penjelasan tersebut menarik peneliti untuk menjadikan ini sebagai kajian penelitian.Permasalahan di atas kemudian dirumuskan dalam pertanyaan penelitian yaitu, Bagaimana modal politik dan modal sosial Athari Gauthi Ardi pada kemenangan pemilu legislatif tahun 2019?

\section{Metode Penelitian}

Metode penelitian kualitatif didefinisikan sebagai metode penelitian ilmu-ilmu sosial yang mengumpulkan dan menganalisis data berupa kata-kata (lisan maupun tulisan) dan perbuatan-perbuatan manusia serta peneliti tidak berusaha menghitung dan mengkuantitatifkan data kualitatif yang telah diperoleh dan dengan demikian tidak menganalisis angka-angka (Afrizal, 
2014) Metode kualitatif merupakan proses penelitian yang menghasilkan data, deskriptif berupa kata-kata tulisan dan lisan dari orang-orang atau perilaku yang dapat diamati. Jenis penelitian ini adalah menggunakan tipe studi kasus.Data penelitian studi kasus bisa diperoleh dari transkip interview, catatan lapangan, foto dan dokumen pribadi, pengamatan langsung (Yin, 2003). Studi kasus menurut (Yin, 2003) adalah menyelidiki fenomena di dalam konteks kehidupan nyata, bilamana batas-batas antara fenomena dan konteks tak tampak dengan tegas, dan dimana multi sumber bukti dimanfaatkan. Lokasi penelitian ini dilakukan di Daerah Pemilihan (Dapil) I Sumatera Barat.Unit analisis dalam penelitian ini adalah individu, yaitu orang-orang yang dekat dan mengetahui kemenangan Athari Gauthi Ardi.Teknik pengumpulan data menggunakan wawancara dan dokumentasi sedangkan pemilihan informan menggunakan purposive sampling.Informannya yaitu, Ali Mukni Ketua DPW Partai PAN Sumatera Barat, Indra Dt Rajo Lelo Sekretaris DPW Partai PAN, Efriyon Coneng Sekretaris DPD Partai PAN, Anggry Nursya Wakil Ketua DPD Partai PAN Kota Solok, M Alghazali Kader Partai PAN Kota Solok, Syadija selaku Ketua Tim Sukes, Asatul Witri sebagai Masyarakat Kota Solok. Teknik analisis data emik dan etik, yang artinya adanya pemahaman pandangan menurut informan pemahaman pandangan menurut informan penelitian. Sedangkan untuk keabsahan data, peneliti menggunakan triangulasi sumber data.

\section{Hasil dan Pembahasan Modal Politik}

Konsep modal dalam konteks politik antara lain dikemukakan oleh Birner dan Witmer (2007). Birner dan Witmer menjadikan konsep modal politik yang memungkinkan untuk mengkaji masyarakat lokal menggunakan modal sosial untuk mencapai sasaran hasil politik. Berbagai kerja politik dilakukan oleh masyarakat lokal untuk mendukung kegiatan-kegiatan politik seperti mobilisasi suara pemilih, partisipasi langsung dalam proses legislasi, protes/demonstrasi, lobi, serta membangun wacana sebagai modal politik untuk membangun demokrasi. Dengan demikian adanya pemanfaatan/penggunaan modal sosial untuk mencapai tujuan tertentu melalui langkah-langkah pengubahan menjadi modal politis. Modal sosial ini dikembangkan menjadi modal politik berupa lobilobi politik dan keleluasaan ekonomi yang memperlancar lobi-lobi politik.

\section{a. Pengalaman Politik}

Dapat dijelaskan, bahwa Athari Gauthi Ardi pernah mencalonkan diri pada pemilu legislatif tahun sebelumya.Athari mencalonkan diri pada pemilu sebelumnya, hanya untuk membantu orang tuanya dan partai PPP dalam memenuhi kuota 30\% perempuan pada pencalonan.Pencalonan yang Athari lakukan memang hanya dikarenakan orang tuanya, tidak atas keinginan Athari sendiri untuk mencalonkan diri.Athari juga melakukannya dengan belajar sekaligus ada pengalaman pencalonannya tersebut. Pada tahun ini, Athari Gauthi mantap untuk mencalonkan diri melalui Partai PAN, karena ada konflik internal yang 
terjadi pada Partai PPP, yang menyebabkan Athari maju diusung oleh Partai PAN.

Pernah nya Athari Gauthi Ardi mencalonkan diri pada pemilu legislatif tahun 2014, menjadi modal awal Athari Gauthi Ardi untuk mengetahui pemetaan suara dan dapat dikenal oleh masyarakat umumnya Kota Solok, walaupun hanya membantu orang tuanya, setidaknya Athari Gauthi sudah memiliki bekal untuk maju ke pemilu legislatif selanjutnya, beliau dapat membenahi kekurangan yang pernah terjadi pada pileg 2014, dan menjadikan sebagai pembelajaran kedepannya untuk dapat lebih baik pada pemilu legislatif tahun 2019 dan menjadikannya sebagai pengalaman politik.

\section{b. Jaringan Orang Tua (Modal Politik Epyardi Asda)}

Adanya penggunaan identitas yang dinyatakan oleh Birner dan Wittmer ,Athari Gauthi menggunakan orang tuanya, Epyardi Asda sebagai indentis yang beliau bangun ditengah masyarakat untuk mengingatkan kembali bahwa orang tuanya sudah banyak berbuat untuk kemajuan Solok Raya pada masa jabatannya. Ingatan seperti itu yang ingin dibangun oleh Athari, agar masyarakat dapat melihatnya sebagai seorang putri Epyardi Asda yang melanjutkan kepemimpinan orangtuanya.

Pernyataan yang sama juga disampaikan oleh Ali Mukhni selaku Ketua DPW Partai PAN Sumatera Barat, bahwasannya tentu ada peran orang tua pada kemenangan Athari Gauthi Ardi pada pemilu legislatif 2019, pengaruhnya memang tidak dapat diukur seberapa besar terhadap kemenangannya tetapi tergantung masyarakat yang memilih. Seperti yang disampaikan oleh Bapak Ali Mukhni pada saat wawancara "bisa jadi, kalau tidak berpengaruh, tidak mungkin di pasang baliho dengan nama orang tuanya, peran orang tuanya juga otomatis membantu.Tetapi kita bisa mempersentasikan berapa persen pengaruhnya.Tetapi jika dikatakan berpengaruh, pasti sangat berpengaruh" (Wawancara dengan Ali Mukhni).

Berita online Republika yang melakukan wawancara dengan Athari Gauthi Ardi juga menyampaikan keuntungan yang Athari Gauthi Ardi yang menjadi anak dari seorang politisi Epyardi Asda.Seperti yang disampaikan oleh media online terkait kemenangan Athari Gauthi Ardi 'Faktor lain yang juga membantunya mengenalkan diri kepada masyarakat, yakni hubungan keluarga. Athari merupakan putri sulung dari mantan anggota DPR RI selama dua periode, Epyardi Asda. Athari juga maju dari dapil yang sama dengan ayahnya, yakni Sumbar I. Menurut Athari, priviledge sebagai anak politisi senior dapat dimanfaatkan untuk mengenal masyarakat di dapilnya" (https://www.msn.com/idid/berita/nasional/cerita-calegterpilih-berjuang-melawan-politikuang/ar-AAGvkEX)

Athari secara tidak langsung mendapatkan dari nama besar orang tuanya, pada saat melakukan kampanye, Athari tidak memfokuskan kampanye di Kota Solok karena sudah dikenal oleh masyarakat Solok Raya sebagai putri dari Epiya Asda. Identitas yang melekat dalam habitus seorang aktor yang tercermin dari hasil konstruksi 
terkait pengalaman aktor memaknai realitas yang dihadapinya.Maka dari itu, aktor membutuhkan marketing politik, yang dilakukan oleh aktor untuk dapat menciptakan strategi berupa Image politik untuk dapat menarik minat masyarakat agar tertarik untuk memilih aktor tersebut pada pemilihan.Kemenangan yang diraih semata-mata bukan karena pengaruh dari eksistensi partainya atau organisasi sosial, melainkan juga kemampuan personal seorang aktor politik yang dapat mempengaruhi masyarakat untuk mendukungnya.Arena politik adalah tempat pertarungan aktor untuk mendapatkan legitimasi ataupun posisi strategis di pemerintahan yang di dalamnya terdapat modal sebagai penunjang tujuan.

\section{c. Dukungan Politik}

Dukungan politik yang didapatkan oleh Athari Gauthi pada pemilihan legislatif tahun 2019, tidak hanya dukungan dari keluarga tetapi juga dukungan dari tokoh-tokoh masyarakat serta niniak mamak beserta masyarakat yang sudah banyak membantu Athari pada masa kampanye. Seperti yang disampaikan oleh Efriyon Coneng menyatakan bahwa "dari tokoh masyarakat yang mendukung Athari, orang tuanya berusaha mengumpulkan simpulsimpul komponen masyarakat dan beliau juga meminta bantu kepada tokoh-tokoh masyarakat Sumatera Barat untuk mendukung anaknya pada pemilihan."

Seperti tokoh agama, adat yang mendukung Athari dengan dukungan secara pribadi saja, ditambah partai PAN merupakan termasuk kelompok Muhammadiyah yang juga di Kota Solok lebih banyak kalangan Muhammadiyah yang pada akhirnya masyarakat memilih Athari di pemilihan.Kemanamgan Athari memang sedikit mendompleng nama dari Bapaknya seperti politik indentitaslah bentuknya. Beliau memang tidak memiliki jabatan di organisasi selain Wasekjen Partai PAN, mungkin beliau banyak menjabat di organisasi terkait bisnis.Athari selalu ikut semua kegiatan partai PAN bersama pimpinan partai PAN di pusat.Organisasi yang mendukung beliau pada pemilihan seperti kelompok ibu-ibu PKK lah" (Wawancara dilakukan dengan Efriyon Coneng)

Dukungan dari organisasi atau kelompok tertentu yang didapatkan oleh Athari Gauthi pada saat pemilihan dapat dikatakan tidak begitu banyak, dikarenakan Athari lebih banyak berkecimpung di dunia bisnis dan hal tersebut dilakukan di Jakarta bersama orang tuanya.Dukungan yang didapatkan oleh Athari hanya dari kelompok masyarakat ibu-ibu PKK dan juga memanfaatkan jabatan Wasekjen untuk menambah jaringan-jaringan pendukungnya di pemilu.

Pendapat lain juga disampaikan oleh Ali Mukhni yang merupakan Ketua Partai PAN DPW Sumatera Barat bahwasannya dukungan partai yang diberikan kepada Athari Gauthi pada saat pencalonan diberikan sangat besar. Bahwasannya Ali Mukhni selaku Ketua Partai PAN DPW Sumatera Barat yang sekaligus menjabat sebagai seorang Bupati Padang Pariaman juga ikut mempromosikan Athari Gauthi kepada seluruh kepala daerah di Sumatera Barat. Dengan memperkenalkan secara langsung Athari Gauthi kepada masing-masing 
kepala daerah, dan meminta secara langsung kepada masing-masing kepala daerah untuk memenangkan Athari Gauthi di daerahnya.Seperti yang dinyatakan oleh Ali Mukhni pada saat wawancara dengan peneliti "kita Partai juga membantu mensosialisasikan Athari kepada kepala daerah dan juga kepada tokohtokoh masyarakat dan saya titipkan Athari, yang merupakan prospek kedepan, jadi untuk itu Bapak dan Ibu pilih pada pemilihan legislatif.Saya mengenalkan Athari baik kepada Walikota dan juga Bupati yang berada pada Dapil Sumbar I saya kenalkan dengan Athari itu.Dan saya juga ikut kampanye yang Athari selenggarakan, seperti ke Sijunjung, Solok dan Dhamasraya.Walaupun berbeda partai dengan kepala daerah di Sumatera Barat tersebut, tetap saya titipkan Athari dengan beliau.Dapat dibilang ya seperti negosiasi dengan kepala daerah, tetapi tetap kita memperhatikan konstituen" (Wawancara dengan Ali Mukhni).

\section{Modal Sosial}

Pierre Bourdieu (1970), mendefinisikan modal sosial sebagai "sumber daya aktual dan potensial yang dimiliki seseorang berasal dari jaringan sosial yang terlembagakan serta berlangsung terus menerus dalam bentuk pengakuan dan perkenalan timbal balik (atau dengan kata lain : keanggotaan dalam kelompok sosial) yang memberikan kepada anggotanya berbagai bentuk dukungan kolektif". Bourdieu juga menegaskan modal sosial sebagai sesuatu yang berhubungan satu dengan yang lain, baik ekonomi, budaya, maupun bentuk bentuk social capital (Baharuddin \& Purwaningsih, 2017)

\section{Modal Ekonomi Athari Gauthi Ardi}

Athari Gauthi seseorang yang merupakan memiliki latar belakang seorang pengusaha, begitupun dengan orang tuanya, sudah menjadi pengusaha yang sukses sebelum mencalonkan diri menjadi wakil rakyat.Persyaratan yang harus dipenuhi oleh kandidat untuk menjalankan roda politik sudah di penuhi oleh Athari Gauthi, dengan latar belakangnya sebagai seorang pengusaha muda yang sukses.Modal ekonomi memiliki peran yang penting untuk menggerakan mesin partai politik, banyak hal yang membutuh uang untuk kelancaran pada masa kampanye. Andri Rusta menyatakan bahwasannya Epyardi Asda merupakan seorang pengusaha sukses, dan sudah sukses sebelum beliau mencalon, jadi tidak heran bahwasannya beliau dapat membayar semua modal ekonomi yang dibutuhkan oleh Athari Gauthi pada masa kampanye. Seperti yang disampaikan oleh Andri Rusta pada saat wawancara "Bapak Epyardi itu seorang pengusaha yang sukses, dia punya usaha kontainer, sekali mengangkut barang itu keuntungannya sangat banyak. Jika hanya untuk memberikan modal kepada anaknya, itu hal yang sangat kecil untuk orangtuanya" (Wawancara dengan Andri Rusta).

Dari wawancara yang sudah peneliti lakukan, bahwasannya Athari memiliki modal ekonomi yang cukup untuk menjalankan tahapan-tahapan pemilihan, walaupun informan tidak menjelaskan dengan nominal kepada peneliti, tetapi informan sudah dapat menjelaskan gambaran besar dari dana kampanye yang Athari gunakan untuk melaksanakan pemilu dinilai 
cukup dan tidak mendapatkan kekurangan pada saat pelaksanaan, karna latar Athari dan kelurganya yang merupakan pengusaha sukses, tidak dipungkiri Athari mampu memenuhi kebutuhan modal ekonomi untuk bersaing di kontestasi politik. Ditambah dengan latar belakang orang tua Athari yang merupakan seorang pengusaha sukses sebelum beliau mencalonkan diri manjadi anggota legislatif.

\section{a. Figur Athari Gauthi Ardi}

Bahwa Athari Gauthi adalah tipe perempuan yang bekerja keras, Athari tidak melihat bahwa perempuan memiliki keterbatasan untuk dapat memajukan daerahnya, tetapi perempuan juga melakukan peran yang penting ditengah-tengah masyarakat. Terbukti dengan Athari melakukan pendekatan secara langsung kepada masyarakat untuk memperkenalkan program dan visi misi yang akan beliau jalankan nantinya.

Pada wawancara dengan media online Republika, Athari Gauthi menyatakan bahwa anggapan caleg perempuan tidak dapat berkontribusi untuk kemajuan daerah, Athari berusaha untuk mematahkan anggapan tersebut, dengan beliau mampu berkontribusi untuk kemujuan Sumatera Barat. Athari Menyampaikan pendapatnya pada Media Online "Apalagi, Athari menjelaskan, selama ini ada anggapan bahwa caleg muda dan caleg perempuan tidak bisa memberikan kontribusi ke masyarakat. "Anak muda, perempuan lagi, bisa apa? Tetapi saya ingin mematahkan anggapan itu.Saya turun langsung ke masyarakat, berangkat pagi, pulang malam.Itu yang bisa dilakukan anak muda seperti saya," kata perempuan 26 tahun ini" (https://www.msn.com/idid/berita/ nasional/cerita-caleg-terpilihberjuang-melawan-politik-uang/arAAGvkEX).

Athari Gauthi juga memberikan pernyataan kepada Republika terkait aksi kampanyenya yang langsung turun ke lapangan untuk dapat bertemu dengan konstituennya.Kita tidak perlu politik uang, masyarakat sudah memahami mana calon yang memiliki kualitas," Athari menjelaskan kampanye turun langsung menyapa konstituen merupakan cara terbaik melawan politik uang. Pada kesempatan ini, ia dapat mengenalkan dirinya lebih dekat kepada warga kata dia dalam diskusi bersama para caleg DPR RI terpilih 2019-2024 di Kantor CSIS, Tanah Abang, Jakarta Pusat (ttps://www.msn.com/idid/berita/n asional/cerita-caleg-terpilih-

berjuang-melawan-politikuang/arAAGvkEX).

Figur Athari lainnya yang peneliti temukan dilapangan, yaitu sosok Athari Gauthi yang fenomenal dan merupakan caleg perempuan yang cantik dan anggun pada baliho kampanye yang digunakan, membuat menarik perhatian masyarakat terhadap sosoknya yang cantik. Dari pemilih menyatakan bahwasannya alasan pemilih tersebut memilih Athari Gauthi Ardi, karena kecantikan yang dimilikinya.Ini merupakan sebuah keuntungan yang berasal dari salah satu potensi yang ada pada diri individu Athari Gauthi Ardi sendiri. Seperti yang disampaikan oleh Witri sebagai salah satu pemilih Athari pada pemilu legislatif tahun 2019.

Dari beberapa figur yang terdapat pada pribadi Athari Gauthi, seperti pribadi yang dekat dengan 
masyarakat, memiliki wawasan yang luas, cerdas, ulet dan juga memiliki good looking yang dapat menarik minat masyarakat untuk dapat memilihnya. Tentu ini merupakan modal sosial pontensial yang Athari Gauthi miliki pada pemilihan legislatif.Tidak hanya memiliki modal jaringan politik orang tuanya, tetapi Athari juga memiliki potensial pada dirinya yang dapat dijadikan produk politik, tentu hal tersebut dapat dijual kepada masyarakat sebagai produk yang lebih unggul dari kandidat lainnya.

Athari Gauthi tentu dengan baik menggunakan modal politik dan modal sosial yang dimiliki oleh orang tua dan dirinya untuk dapat memenangkan pemilu legislatif tahun 2019.Terbukti modal yang paling berpengaruh adalah modal politik yang dimiliki oleh Epyardi Asda mampu dimanfaat oleh Athari dengan sangat baik.Karena dari data yang peneliti temukan dilapangan, bahwasannya Athari Gauthi Ardi tidak lepas dari bantuan orang tuannya. Upaya marketing politikyang dilakukan Athari, dengan menggunakan nama orang tuanya di baliho kampanye serta membawa orang tuanya untuk turun ke daerahdaerah pemilihan, yang merupakan basis massa suara orang tuanya terdahulu. Athari bertujuan agar pemilih dapat mengingatkan kembali kepada masyarakat bahwa orang tuanya yang sudah berbuat banyak untuk Solok Raya.Tentu modal yang dimiliki oleh Athari Gauthi Ardi dapat mempengaruhi kemenangannya pada pileg 2019.

\section{Marketing Politik Athari Gauthi Ardi}

Bogazzi (1947) Dalam

(Firmanzah, 2008) melihat bahwa marketing adalah proses yang memungkinkan adanya pertukaran (exchange) antara dua pihak atau lebih. Artinya, marketing akan selalu ditemui dalam proses pertukaran. Dalam pertukaran terdapat proses hubungan (relation) yang memungkinkan interaksi, dimana dalam prosesnya masing-masing pihak ingin memaksimalkan dan menjamin bahwa kepentingannya sendiri akan terpenuhi. Dalam proses ini satu pihak bersedia memberikan sesuatu untuk mendapatkan sesuatu yang lain

\section{Produk yang ditawarkan Athari Gauthi Ardi}

Produk (product) yang ditawarkan kandidat merupakan sesuatu yang kompleks, dimana pemilih akan menikmatinya setelah sebuah partai atau seseorang kandidat terpilih. Artinya produk politik tidak hanya ditentukan oleh karakteristik produk itu sendiri.Pemahaman pemilih juga memainkan peranan penting dalam memaknai dan menginterpretasikan sebuah produk politik. Athari Gauthi Ardi menyatakan bahwa produk politik yang digunakannya pada saat kampanye seperti, visi dan misi, program kerja, spanduk, jilbab, baju dan juga alat peraga kampnye lainnya.Athari mengatakan "logistik berupa alat peraga kampanye memang penting sebagai bagian dari mengenalkan diri kepada masyarakat (https://www.msn.com/idid/berita/nasional/cerita-calegterpilih-berjuang-melawan-politikuang/ar-AAGvkEX)

Tentu alat perega tersebut yang sudah merupakan keharusan bagi calon anggota legislatif untuk memperkenalkan diri kepada masyarakat. Bagi Athari Gauthi Ardi 
hal tersebut bukanlah hal yang sulit, dengan kemampuan modal ekonomi yang cukup, Athari bisa dengan mudah menyediakan alat-alat tersebut.Syajida juga mengatakan bahwa Athari juga memiliki relawan untuk membagikan dan memasang alat-alat peraga kampanye Athari Gauthi di daerah Kota Solok. Seperti yang disampaikan oleh Syajida 'Athari punya tim khusus untuk membagi-bagikan kampanye seperti jilbab, baju, kalender kepada masyarakat, kususnya Kota Solok saja, dan juga tim untuk pemasangan spanduk di daerah-daerah pemilihan beliau (Wawancara dengan Syadija).

Alat peraga seperti baliho Athari Gauthi Ardi disertai dengan nama orang tuanya, bahwasannya salah satu modal politik yang dimilikinya adalah nama besar orangtuanya, untuk itu penamaan pada baliho salah satu strategi yang dimiliki oleh Athari Gauthi Ardi untuk dapat menarik simpati masyarakat pada pemilihan.

Visi misi yang ditawarkan oleh Athari Gauthi Ardi adalah visi dan misi yang sama dengan orang tuanya. Yang lebih memfokuskan pada pembangunan dan infrastruktur di daerah Sumatera Barat, untuk itu Athari Gauthi memilih dan menyampaikan ke masyarakat keinginannya untuk memilih komisi $\mathrm{V}$, yang bertujuan untuk melanjutkan pembangunan yang masih terbengkalai pada masa kepemimpinan ayahnya. Salah satu modal politik yang dimanfaatkan dari nama besar orangtuanya, untuk dijadikan produk bagi Athari Gauthi Ardi pada saat pemilihan.

Syajida selaku ketua Tim Sukses Athari Gauthi "karena saya disini tujuannya untuk melanjutkan perjuangan Ayahanda, Beliau dulu hampir 3 periode di komisi V DPR RI.Nah, pembangunan-pembangunan beliau banyak dirasakan langsung oleh masyarakat, inilah yang menjadi cambuk bagi saya sebenarnya. Kalau tidak ada yang melanjutkan perjuangan itu, kan sayang sekali. Banyak jalan-jalan yang sudah dibangun oleh Ayahanda, ingin saya lanjutkan kembali perjuangan selama 5 tahun ke depan (Wawancara dengan Syadija).

Produk dalam penyelenggaraan pemilu sangatlah penting bagi masing-masing kandidat, karena hal tersebut sangat berguna bagi pengenalan kandidat kepada masyarakat yang akan memilihnya. Untuk itu Athari juga menggunakan produk politik guna mempromosikan dirinya kepada masyarakat, Athari juga dibantu oleh tim relawan yang menangani terkait alat peraga serta atribut kampanye tersebar kesemua daerah di Sumatera Barat. Tentu dengan logistik yang harus dipersiapkan oleh Athari Gauthi.

\section{a. Promosi yang dilakukan Athari Gauthi Ardi}

Seperti yang dinyatakan oleh Bogazzi bahwa marketing adalah proses yang memungkinkan adanya pertukaran (exchange) antara dua pihak atau lebih. Artinya, marketingakan selalu ditemui dalam proses pertukaran. Dalam pertukaran terdapat proses hubungan (relation) yang memungkinkan interaksi, dimana dalam prosesnya masingmasing pihak ingin memaksimalkan dan menjamin bahwa kepentingannya sendiri akan terpenuhi. Dalam proses ini satu pihak bersedia memberikan sesuatu 
untuk mendapatkan sesuatu yang lain (Firmanzah, 2008) Melakukan kerjasama dengan caleg-caleg tokoh di masing-masing daerah di Dapil I Sumatera Barat, merupakan suatu keuntungan bagi Athari Gauthi untuk dapat mengenalkan dirinya ke masyarakat.Athari Gauthi tidak hanya dipromosikan dengan menggunakan alat peraga kampanye saja, seperti yang dapat terlihat oleh masyarakat yaitu baliho, tetapi Athari juga di promosikan secara langsung oleh caleg-caleg per daerah kepada masyarakat. Tentu ini merupakan cara efektif yang dilakukan Athari untuk dapat mengenalkan dirinya pada masyarakat.

Bentuk-bentuk promosi seperti program, visi dan misi yang Athari sampaikan kepada masyarakat saat kampanye juga melanjutkan apa yang sudah lakukan dan belum terselesaikan oleh orang tuanya pada saat masa menjabat. Itu dilakukan untuk menarik pemilih untuk memilihnya.Dengan kinerja orang tuanya yang bagus, Athari mencoba menggunakan hal tersebut untuk mempromosikan dirinya ke masyarakat, agar dapat melanjutkan perjuangan orang tuanya di legislatif.

\section{Dalam}

PolitikProdusen

Marketing

memperkenalkan dan membawa produk serta jas yang dihasilkn kepada konsumen.Semua usaha marketing dimaksudkan untuk meyakinkan konsumen bahwa produk yang dijual memang memiliki kualitas yang lebih baik dibandingkan produk yang dijajakan pesaing. Cara yang dilakukan Athari Gauthi Seperti yang disampaikan oleh Asrinaldi, bahwasannya Athari melakukan pembuat baliho yang disertai dengan nama orang tuanya Bapak Epyardi
Asda, serta melakukan kampanye dengan membawa ikut serta orang tuanya, agar dapat mengingatkan kembali pemilih, bahwasanya beliau merupakan putri dari Bapak Epyardi Asda. Konstituen dapat diingatkan kembali dengan kepemimpinan Bapak Epyardi Asda, dan orang tua Athari juga menyampaikan bahwasannya, Athari akan melanjutkan kekurangan dari visi dan misi orangtuanya. Promosi ini merupakan salah satu cara efektif yang dilakukan oleh Athari Gauthi dan orang tuanya agar masyarakat percaya untuk memilih Athari Gauthi pada pemilihan.

Bentuk promosi yang dilakukan oleh Athari Gauthi Ardi pada saat melakukan kampanye ditengah-tengah masyarakat yaitu dengan memperkenalkan dirinya ke masyarakat, bahwa dirinya merupakan anak dari Bapak Epyardi Asda, anggota legislatif yang sudah mengabdi untuk masyarakat Sumatera Barat selama tiga periode. Athari juga menggunakan visi dan misi yang tidak jauh berbeda dengan orang tuanya kerjakan selama menjabat dan berjanji untuk melanjutkan pekerjaan orang tuanya yang belum terselesaikan pada masa menjabat, akan dilanjutkan oleh dirinya. Begitupun orang tuanya, berusaha memperkenalkan Athari kepada konstituennya terdahulu, bahwasannya Athari adalah anaknya dan akan membangun Sumatera Barat lebih maju lagi untuk kedepannya. Selanjutnya, Athari juga meminta bantuan kepada caleg-caleg Partai PAN di daerah pemilihan Dapil I Sumatera Barat untuk memperkenalkan dirinya ke masyarakat, dengan cara menyandingkan foto Athari dengan 
caleg lainnya pada satu baliho, agar Athari dapat dikenal oleh masyarakat di daerah pemilihannya.

Dapat dilihat pada data yang peneliti temukan dilapangan, banyaknya produk yang dipromosikan oleh Athari Gauthi Ardi memiliki kaitan dengan Epyardi Asda.Tentu modal tersebutlah yang dipromosikan oleh Athari Gauthi kepada masyarakat, untuk dapat menghasilkan simpati masyarakat, yang pada akhirnya mendapatkan kepercayaan masyarakat untuk memilihnya pada pemilu legislatif. Tentu pada kemenangan Athari Gauthi Ardi dapatkan tidak terlepas dari campur tangan, nama besar, serta kekuasaan yang dimiliki oleh orang tuanya.

\section{Kesimpulan}

Dari hasil interpretasi data yang telah peneliti lakukan berdasarkan dari hasil penelitian di bab-bab sebelumnya maka peneliti menarik kesimpulan sebagai berikut : Pertama, seperti yang dikemukakan oleh Birner dan Witmer. Birner dan Witmer menjadikan konsep modal politik yang memungkinkan untuk mengkaji masyarakat lokal menggunakan modal sosial untuk mencapai sasaran hasil politik. Seperti yang dilakukan oleh Athari Gauthi Ardi, mampu menjadikan modal sosial yang sudah dimiliki oleh orang tuanya, untuk dapat memenangkan kontestasi politik. Dilihat dari modal politik dan modal sosial yang dimiliki oleh Athari Gauthi Ardi, bahwasannya yang lebih mendominasi kemenangan Athari Gauthi Ardi adalah modal politik yang dimiliki oleh Athari Gauthi Ardi, dimana modal tersebut berasal dari modal yang sudah dimiliki oleh orang tuanya Epiyardi Asda.

Kedua, Marketing Politik menjadi strategi bagi Athari Gauthi Ardi untuk mempromosikan produk yang dimilikinya, bahwasannya produk yang dipromosikannya kepada masyarakat memiliki hubungan dengan orang tuanya, seperti (1) Melakukan kampanye dengan membawa orang tuanya Epyardi Asda dan lebih intens di daerah basis massa orang tuanya. (2) Baliho dengan menggunakan nama orang tunya. (3) Postingan di Facebook dengan menandai nama orang tuanya. (4) Perkenalan Athari Gauthi kepada kepala daerah di Sumatera Barat oleh Ali Mukhni. (5) Melakukan kerja sama dengan caleg dari Partai PAN di daerah Dapil I.

\section{Referensi}

Afrizal. (2014). Metode Penelitian Kualitatif: Sebuah Upaya Mendukung Penggunaan Penelitian Kualitatif Dalam Berbagai Disiplin Ilmu. PT Raja Garfindo Persada.

Baharuddin, T., \& Purwaningsih, T. (2017). Modalitas Calon Bupati Dalam Pemilihan Umum Kepala Daerah Tahun 2015. Journal of Governance And Public Policy, 4(1), 206-237.

Bungin Burhan (2009). Metodologi Penelitian Kualitatif. Jakarta, Rajawali Pers.

Cici Safitri. (2019). Pengaruh Modal Sosial Dalam Kemenangan Mahyeldi Ansyarullah-Hendri Septa Pada PILKADA 2018. Skripsi. Universitas Andalas

Firmanzah. (2008). Marketing Politik. Yayasan Obor Indonesia. 
Lumiu Vandyk. (2014). Partisipasi Politik Perempuan Dalam Pemilu Legislatif Tahun 2014 Di Kecamatan Siau Barat Selatan. Skripsi. Universitas Sam Ratulangi

Nasira. (2016). Pemasaran Politik (Political marketing)Pasangan Herman Hn dan Yusuf Kohar pada Pilkadabandar Lampung Tahun 2015 (Studi Kasus Kelompok Pengajian Majelis Taklim Rachmat Hidayat). Skripsi. Universitas Lampung

Nimrah Siti dan Sakaria. (2015). Perempuan Dan Budaya Patriaki Dalam Politik (Studi Kasus Kegagalan Caleg Perempuan Dalam Pemilihan Legislative 2014). Universitas Hasanudin. 2 (1)

Noverika Reno. (2016). Optimalisasi Modal Politik Betti Shadiq Pasadigoe Dalam Pemilihan Legislatif 2014. Skripsi. Universitas Andalas

Pierre Bourdieau. (2010) Arena Produksi Kultural Sebuah Kajian Sosiologi Budaya. Pereum Sidorrejo Bumi Indah: Kreasi Wacana Offset

Ria, I., Plaituka, R., Azhar, M. A., \& Noak, P. A. (2014). Pemanfaatan Modal Sosial Dalam Pindah Dapil Pada Pemilu Legislatif Kota Surabaya Tahun 2014. Universitas Udayana. 1-11.

Ria, I., Plaituka, R., Azhar, M. A., \& Noak, P. A. (2014). Pemanfaatan Modal Sosial Dalam Pindah Dapil Pada Pemilu Legislatif Kota Surabaya Tahun 2014. 111.

Solihah, R. (2019). Modal sosial JejeAdang dalam Pemilihan Kepala Daerah Kabupaten Pangandaran
Tahun 2015. Jurnal Wacana Politik, 4(1), 30-43.

Sugiyono. (2012). Metode Penelitian Kuantitatif Dan R\&D. Bandung, Alphabet.

Syahra Rusydi. (2003) Modal Sosial: Konsep Dan Aplikasi. Peneliti pada Puslit.Kemasyarakatan dan Kebudayaan (PMB) LIPI, Jurnal Masyarakat dan Budaya, 5 (1)

Yin, R. K. (2003). Studi Kasus, Desain Dan Metode. PT Raja Grafindo Persada.

\section{BERITA ONLINE}

Athari Gauthi Puncaki Perolehan Suara Caleg DPR RI di Kabupaten

Solok,https://www.kabarsumb ar.com/berita/athari-gauthipuncaki-perolehan-suara-calegdpr-ri-di-kabupaten-solok/. Dilihat pada tanggal 9 juli 2019.

Cerita Caleg Terpilih Berjuang Melawan Politik Uang, https://www.msn.com/idid/berita/nasional/cerita-calegterpilih-berjuang-melawanpolitik-uang/ar-AAGvkEX. Dilihat pada tanggal 28 November, pukul 23.08 wib.

Empat Petahana DPR RI dari Sumbar yang Tak Lagi Lolos, https://www.kabarsumbar.com /berita/empat-petahana-dpr-ridari-sumbar-yang-tak-lagilolos/.Dilihat pada tanggal 24 juni 2019.

Epyardi Asda : Athari Gauthi Siap Lanjutkan Perjuangan Saya di DPR RI, https://sumbarpost.com/epyar di-asda-athari-gauthi-siaplanjutkan-perjuangan-saya-didpr-ri/. Diakses pada tanggal 9 Juli 2019. 
Rumah Bagonjong, Impian Epyardi Asda Membangun Sumbar. http://reportaseinvestigasi.com Lnews0612/rumah-bagonjongimpian-epyardi-asdamembangun sumbar/. Dilihat pada tanggal 29 November 2019. Pada jam 12.11 wib.

Sejarah Terjadi, Tiga Caleg Perempuan Asal Sumbar Lolos ke Senayan https://regional.kompas.com/r ead/2019/05/18/16544831/se jarah-terjadi-tiga-caleg perempuan-asal-sumbar-loloske-senayan. Dilihat pada tanggal 24 juni 2019.

3 Istri Kepala Daerah Di Sumbar Melenggang Ke Senayan ,https://kilasdaerah.kompas.co m/jawatengah $/ \mathrm{read} / 2019 / 05 / 13 / 120$ 50771/3-istri-kepala-daerah-disumatera-barat-melenggang-kesenayan. Dilihat pada tanggal 29 juni 2019. 